ПЛОСКОНОС В. Г., к.т.н., доц.

Національний технічний університет України «Київський політехнічний інститут імені Ігоря Сікорського»

\title{
СИСТЕМНИЙ ПІДХІД ДО ВИЗНАЧЕННЯ ТА АНАЛІЗУ ТЕХНОЛОГІЧНИХ ПРОБЛЕМ В СИСТЕМАХ ВИРОБНИЦТВА ПАПЕРУ ТА КАРТОНУ 3 МІНІМАЛЬНИМ СПОЖИВАННЯМ СВІЖОЇ ВОДИ
}

Використано методологію системного підходу до складних систем з метою виявлення та аналізу проблем в системах водокористування виробництва паперу та картону з мінімальним споживанням свіжої води, щзо використовується на технологічні потреби. Визначено фактори, зміна яких впливає на стан технологічної системи виробництва, а також рівні їх варіювання з метою подальшої розробки максимально інформативної та шумостійкої матриці експериментальних досліджень та математичних моделей, які можливо використовувати для прогнозування стану системи.

Ключові слова: складна система, система водокористування, мінімальне споживання свіжої води, фактори, стан технологічної системи виробництва паперу та картону, матриця експериментальних досліджень.

(C) Плосконос В. Г., 2018

Постановка задачі. Захист навколишнього природного середовища від промислових викидів можливий за умови переведення діючих підприємств целюлозно-паперової галузі, а також тих, що проектуються на маловідходну і безвідходну технології виробництва. При цьому питомі норми споживання свіжої води на виробничі потреби зводяться до мінімуму, тобто ставиться задача створення технологічних систем, близьких до замкнутих. Цього можна досягти шляхом інтенсифікації використання води, що циркулює в технологічному процесі системи виробництва.

Разом з тим, однією із основних причин, за якими практично неможливо ізолювати систему зворотного водокористування картонно-паперового виробництва від навколишнього середовища, виступає факт накопичення в зворотних і стічних водах водорозчинних мінеральних і органічних речовин до рівнів, які викликають інтенсивну корозію технологічного обладнання, а також перешкоджають нормальному протіканню технологічного процесу.

Аналіз попередніх досліджень. Спроби відтворити на одному із діючих підприємств галузі технологічні умови підприємства целюлозно-паперової галузі, що проектується не дають бажаних результатів, оскільки кожне підприємство - це складний об'єкт, який характеризується тільки йому присутньою множиною різних вузлів і апаратів, що функціонують в певному режимі, а також оригінальною структурою їх взаємозв'язку. А в умовах інтенсифікації використання зворотних вод у виробничому процесі настільки зростає взаємовплив вузлів (апаратів), що неможливо наперед знати, як відіб'ються зміни в структурі технологічної системи виробництва або режимі роботи окремих апаратів (навіть одного із них) на функціонуванні інших вузлів (апаратів) та на стані водопотоків технологічної системи.

Невирішеною частиною проблеми з практичної точки зору $є$ недостатній розвиток ідей замкнутого водокористування. Багато в чому це залежить від розроблення теоретичних основ методології дослідження динаміки функціонування складних систем [1] та практичних рекомендацій стосовно стабілізації якості води в зворотних циклах водокористування, удосконалення методів аналізу і розрахунків концентрації забруднюючих речовин, а також прогнозування закономірностей їх накопичення в стічних водах в результаті скорочення питомого споживання свіжої води.

Метою даної статті $\epsilon$ використання системного підходу, який дасть можливість визначити впливові фактори в процесі аналізу проблем, що виникають в технологічних системах виробництва паперу та картону зі складною структурою взаємодії іiі елементів [2] та мінімальним споживанням свіжої води на виробничі потреби. Це дозволить в подальшому сформувати інформативний і шумостійкий план проведення експериментальних досліджень та розробити математичні моделі з метою прогнозування можливих станів технологічної системи.

Виклад основного матеріалу. В процесі замикання системи водокористування картонно-паперового виробництва, коли питомі норми споживання свіжої води на виробничі потреби мінімізуються, можлива поява наступних основних негативних явищ:

- концентрування мінеральних електролітів;

- підвищення концентрації водорозчинних органічних речовин;

- накопичення дисперсних часток;

- акумулювання теплової енергії і, як наслідок, підвищення температури водопотоків.

Рівень мінералізації електролітів у воді, що циркулює в замкнутих системах водокористування, може підвищуватися до $11 \mathrm{r} \mathrm{dm}^{3}$. При цьому, переважно накопичуються сульфати, хлориди та катіони кальцію. Присутність в зворотних водах сульфатів, карбонатів або оксалатів в сполученні з катіонами кальцію, 
магнію, марганцю, заліза, алюмінію і барію є джерелом більшості відкладень солей кальцію та магнію, а також інших утруднень, що виникають в процесі виробництва паперу та картону.

Однією із головних проблем, що виникають в результаті багатократного використання зворотних вод, $є$ також корозія, яка руйнує технологічне обладнання в результаті того, що відбуваються електрохімічні, хімічні та біохімічні процеси. На швидкість протікання корозії впливають такі фактори, як рН середовища, кількість розчиненого кисню, концентрація сульфатів, хлоридів, загальна кількість розчинених мінеральних речовин, жорсткість води, лужність або кислотність середовища, температура, концентрація вуглекислого газу та інші фактори. Зокрема, за наявності сульфат-іонів, які э одним із основних компонентів, що накопичуються в системах зворотного водокористування, інтенсивно розвиваються сульфат відновлювальні бактерії, що також відмічається в літературі на дану тему. Результатом діяльності цих бактерій є сірководень, який ініціює процес корозії трубопроводів і обладнання. Також ці бактерії можуть використовувати катодний водень, присутність якого є бажаною, тому що це сприяє сповільненню або навіть припиненню процесу корозії.

Накопичення водорозчинних органічних речовин, які сумарно характеризуються показниками біологічного споживання кисню мікроорганізмами протягом 5 діб (БСК 5 ) або хімічного споживання кисню, що показує потребу в кисні для окислення всіх органічних речовин, які містяться у воді під впливом сильних хімічних окиснювачів (ХСК), виявляє негативний вплив на властивості паперу (картону). Так деякі автори відмічають, що після 48 годин роботи на промисловій папероробній машині в замкнутому циклі водокористування спостерігалося різке зниження міцності паперу та ступеня його проклеювання.

Особливі ускладнення в технологічному процесі картонно-паперового виробництва викликає наявність в зворотних водах дисперсних часток. Їх накопичення призводить до засмічування сіток паперокартонноробних машин, зростанню чисельності мікроорганізмів, що, в кінцевому варіанті, визиває інтенсивне утворення слизу на обладнанні, а також інші технологічні ускладнення.

Як витікає з літературних джерел, спроби фізичного моделювання, а також досліди на досліднопромислових установках дозволяють виявити лише окремі аспекти явищ, що виникають в замкнутих системах водокористування, але не дають однозначної відповіді на питання, яким чином зміниться стан зворотних і стічних вод (ступінь їх забруднення) в залежності від варіювання одного або декількох факторів технологічного процесу. Серед цих факторів можливо виділити такі: споживання і якість свіжої води, вид і якість вихідних волокнистих напівфабрикатів, параметри технологічного процесу, види хімічних допоміжних речовин, що використовуються, компоновка технологічного обладнання та інші.

Разом з тим, аналіз результатів, показує, що отримані дані не завжди узгоджуються між собою. Це можливо пояснити тим, що дослідження проводилися не в ідентичних умовах і за різного співвідношення схем технологічного процесу, систем водокористування і очистки стічних вод, а також інших факторів. В цьому випадку зберігаються лише загальні тенденції та закономірності, а якісні показники забрудненості зворотних і стічних вод багато в чому залежать від конкретних виробничих умов.

Таким чином, напрошується висновок, що необхідно застосовувати системний підхід до аналізу таких систем з використанням сучасних засобів обчислювальної техніки та математичного моделювання.

Специфіка складних технологічних систем, до яких відносяться системи виробництва паперу та картону 3 мінімальним споживанням свіжої води, вимагає розглядати зовнішнє середовище в якості основного джерела забруднення мінеральними і органічними речовинами. 3 цією метою належить виявити та вивчити всі джерела надходження хімічних речовин (впливові чинники - фактори), виходячи з режимів виготовлення паперу і картону, враховуючи при цьому найближчі перспективи використання нових видів сировини i допоміжних хімічних речовин.

В першу чергу - це фактори, які характеризують склад волокнистої сировини. Отже, волокниста сировина є одним із джерел забруднення водопотоків картонно-паперового виробництва водорозчинними мінеральними і органічними речовинами. Однак дані про кількісний і якісний склад цих речовин у літературі практично відсутні.

Таким чином, з метою визначення питомої кількості водорозчинних забруднень у волокнистій сировині досліджували целюлозу різних видів, деревну масу і макулатуру. В процесі визначення цього показника в макулатурі утруднення полягали в тому, що за основу сортування вторинної сировини за марками прийнято принцип композиційного складу маси за волокном, ступенем забруднення і кольором. Враховуючи, що 3 метою вдосконалення способу розподілу вторинної сировини на певні групи, викликаного вимогами виробництва, постійно відбуваються зміни в марках макулатури, зручно подати мінімальні і максимальні значення питомих забруднень, що вимиваються із вторинної сировини.

Так, в 1 т макулатури вміст сульфатів може коливатися від 0,2 до 0,5 кг, хлоридів - від 0,2 до 1,5 кг. Вміст катіонів магнію може досягати в середньому 0,1 кг, натрію - від 0,1 до 1,5, кальцію - 0,3 - 0,9 кг.

Визначення аналогічних показників в інших видах волокнистих напівфабрикатів (целюлоза, деревна маса) показало, що вміст їх менше піддається коливанням. Так, вміст катіонів кальцію і магнію в основному стабільний і тримається, відповідно, на рівні 0,3 і 0,1 кг. Вміст сульфатів коливається від 0,1 до 0,5 кг, хлоридів - від 0,3 до 0,5, а натрію - від 0,1 до 0,2 кг.

Разом з тим, водорозчинні органічні речовини, які вимиваються з волокнистої сировини, вирізняються за своїм складом для різних видів сировини. Причина в тому, що однаковій кількості розчинених органічних речовин можуть відповідати різні показники БСК 5 і ХСК. Тому, 3 метою перерахування розчинених 
органічних речовин у показники БСК 5 і ХСК потрібно додатково враховувати співвідношення показників ХСК/БСК і БСК $_{5} /$ розчинені органічні речовини, тобто вводити додатково ще два фактори.

Наступний крок - детальне ознайомлення з технологічними регламентами виробництва паперу і картону та проведення серії експериментів. Це дало можливість простежити закономірності впливу окремих факторів, які відносяться до групи технологічних, на процес розчинення мінеральних і органічних речовин, що втримуються у волокнистій сировині. Природно, що при цьому розглядалися технологічні процеси виробництва паперу i картону, що включають етапи розмелювання волокнистих напівфабрикатів, сортування і очищення волокнистої суспензії і наступного відливання паперового (картонного) полотна.

Як випливає із технологічних регламентів, концентрація маси на стадії ії підготовки перебуває в межах

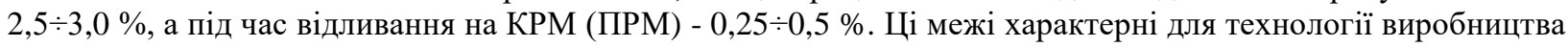
картонно-паперової продукції, у композиції якої використовується макулатура.

Як показує досвід роботи підприємств галузі, ступінь млива маси знаходиться в межах від 25 до $45{ }^{0} Ш Р$, тоді як потоки маси, що містять целюлозне волокно, можуть мати і більш низьку ступінь млива маси - $18 \div 25$ ${ }^{0}$ ШР. Підвищення показника ступеня млива до $50{ }^{0}$ ШР можливе в результаті того, що концентрація мінеральних і органічних зважених у зворотних водах, що використовується для розбавлення маси,

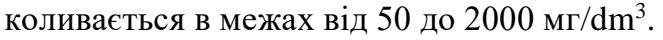

Разом $з$ тим, середня температура водопотоків, в залежності від періоду року, коливається в інтервалі від 18 до $38^{\circ} \mathrm{C}$. Оскільки в процесі проектування картонно-паперових підприємств, що переробляють макулатуру, можливе додавання процесу термічної обробки макулатурної маси, інтервал коливань температури необхідно розширити до $90{ }^{\circ} \mathrm{C}$. Також 3 метою вивчення впливу тривалості контакту маси 3 водою на кількість десорбованих мінеральних і органічних речовин, тривалість контакту під час проведення експериментальних досліджень установлюється в межах 15-120 хвилин. При цьому час 2 години взято із розрахунку, що в умовах виробництва для нормальної роботи підприємства зазвичай створюється двохгодинний запас маси.

В ході проведення однофакторних експериментів встановлено, що водорозчинні мінеральні речовини в процесі контакту з першими дозами виробничої води практично повністю переходять в розчин, тому подальша зміна технологічних факторів в зазначених вище інтервалах не виявляє замітного впливу на процес десорбції іонів із волокнистої сировини. Разом з тим, підвищення температури макулатурної маси вище 40 ${ }^{\circ} \mathrm{C}$ дещо підвищує кількість іонів, що вимиваються. Але це підвищення проявляється, в основному, за росту температури вище $80{ }^{\circ} \mathrm{C}$. Враховуючи ті обставини, що з волокнистою сировиною надходить значно менше водорозчинних мінеральних речовин, ніж з мінеральними добавками, знехтування цим фактом не вносить значної похибки в подальші розрахунки.

Наведені вище передумови дозволяють зробити висновки, що процес екстракції мінеральних речовин, які знаходяться в волокнистих напівфабрикатах, можливо описати залежністю, 3 якої слідує, що концентрація на виході відділу (підсистеми) підготовки маси дорівнює сумі мінеральних речовин, що надходять (з врахуванням розчинного і нерозчинного станів), поділеної на сумарний обсяг вхідних водопотоків.

Разом 3 тим, концентрація водорозчинних органічних речовин, а також показники БСК 5 і ХСК в зворотних водах, які використовуються в технологічному процесі взамін свіжої води, залежать від багатьох факторів.

Так, в процесі коливання концентрації маси відбувається також зміна концентрації водорозчинних мінеральних і органічних речовин. Разом з тим, прямої пропорційності не спостерігається, особливо за низьких температур. 3 іншого боку, з підвищенням ступеня млива маси інтенсифікуються процеси екстракції водорозчинних органічних речовин. Але, для всіх видів волокнистої сировини приріст ступеня млива вище 50 ㅍ практично не інтенсифікує процес десорбції водорозчинних органічних речовин, а в деяких випадках відбувається навіть зниження концентрації органічних речовин за рахунок збільшення питомої поверхні волокнистого матеріалу та сорбції на його поверхні водорозчинних органічних речовин.

Підвищення температури в процесі гарячої обробки маси (в лабораторних умовах проба витримувалася на протязі 1 години на гарячій бані за температури $90{ }^{\circ} \mathrm{C}$ ) сприяє додатковому вимиванню водорозчинних речовин органічного походження. Це ще один із факторів, що відноситься до групи технологічних.

Значний вплив на сорбцію водорозчинних органічних речовин із волокнистої сировини в процесі виробництва має якість вихідної води. Відомо, що в технологічних системах, які наближені до замкнутих, лише в початковий момент роботи системи використовується свіжа вода. В подальшому основним транспортним засобом маси служить зворотна вода, яка не однократно вступала в контакт 3 масою та хімікатами. Підвищення концентрації водорозчинних органічних речовин у такій воді певним чином сповільнює швидкість екстракції в результаті зменшення градієнта концентрацій органічних речовин в порах волокна.

Таким чином, процес екстракції водорозчинних органічних речовин із волокнистих напівфабрикатів потребує додаткового вивчення та врахування комплексного впливу всіх перерахованих вище факторів.

Разом $з$ тим, в процесі виробництва паперу та картону широко використовуються допоміжні хімічні речовини (ДХР), які можна віднести до досить сильних джерел забруднення водопотоків виробництва паперу та картону водорозчинними органічними речовинами. До них відносяться, в основному, проклеювальні речовини, а також ДХР, що використовуються для підвищення ступеня утримання дрібного 
волокна, наповнювача, проклеювальних речовин, а також під час очищення стічних вод. В деяких випадках використовуються і інші добавки. Наприклад, з метою облагородження поверхні паперового (картонного) полотна, нанесення покриттів, придання паперу (картону) властивостей вологоміцності, для погашення піни та ін.

В результаті аналізу технологічних регламентів виробництва паперу та картону визначається перелік ДХР, що використовуються в цих виробництвах, а також враховується її питома витрата.

Під час визначення кількості неорганічних речовин, що переходять в розчин, необхідно, в першу чергу, виходити із вмісту активного продукту (у відповідності із ДСТУ, ГОСТ або ТУ на даний продукт).

Разом $з$ тим, для багатьох ДХР (за виключенням каустичної соди, сірчаної кислоти, хлористого калію, які мають високу розчинність, а також наповнювачів, які у воді практично не розчиняються) недостатньо знати тільки долю активної речовини в товарному продукті. За такого підходу деякі елементи, що переходять у воду в процесі виробництва паперу та картону, можуть бути не враховані.

Отже, для визначення кількості мінеральних допоміжних речовин, що перейшли в розчинний стан, необхідно враховувати ще і технологічні фактори, що проявляються на стадії, на якій ці ДХР вносяться. Так, наприклад, сірчанокислий алюміній, що використовується в процесі проклейки паперу та картону вступає в реакцію з резинатом натрію, в результаті якої відбувається заміщення натрію еквівалентною кількістю алюмінію, а сульфат-іони практично повністю переходять у воду.

Для вивчення утримання картонним (паперовим) полотном сульфат-іонів, які наслідком використання сірчанокислого алюмінію, проведено розрахунки балансу сульфатів на двох діючих виробництвах. В результаті проведених замірів і розрахунків установлено, що середній коефіцієнт утримання сульфат-іонів картонним полотном дорівнює 8,3 \% (приблизно та кількість, що виноситься водою, яка міститься у полотні, що надходить на сушіння). Відповідно, 91,7 \% сульфат-іонів переходять в розчин і поступово накопичуються у водопотоках картонно-паперового виробництва.

В процесі використання сірчанокислого алюмінію в якості коагулянту для очищення стічних вод, катіон алюмінію за рН, що дорівнює 5,5-7,0, практично кількісно переходить в осад, а кількість сульфат-іонів, які переходять у воду, коливається в межах від 88,9 до 98,4 \%. Отримані результати узгоджуються 3 теорією коагуляції.

В ході експериментальних досліджень також установлено, що в процесі облагородження макулатури хімічні сполуки натрію, сприяючи набряканню целюлозних волокон та диспергуванню друкарських фарб, не утворюють стійких хімічних сполук. Частково сорбуючись волокнистими матеріалами в лужному середовищі, натрій після нейтралізації маси повністю переходить у воду у вигляді розчинних сполук.

Таким чином, в ході попередніх досліджень складної технологічної системи виробництва паперу та картону визначені практично всі фактори та визначено їх вплив на стан зворотних та стічних вод.

Невивченим залишається питання комплексного впливу факторів, що визначають процес екстракції водорозчинних органічних речовин із волокнистої сировини, що використовується під час виробництва паперу та картону. Тому для подальшого вирішення цього питання необхідно, в першу чергу, розробити матрицю експериментальних досліджень, провести експерименти, які послужать базою для створення математичних моделей досліджуваних процесів.

Висновки

3 метою побудови матриці експериментальних досліджень визначено групи факторів та рівні їх варіювання, а саме:

група факторів, що характеризують вихідну волокнисту сировину:

$\mathrm{X}_{1}$ - вміст водорозчинних органічних речовин у волокнистій сировині: $10,0 \div 31,0, \mathrm{\kappa} / \mathrm{T}$;

$\mathrm{X}_{2}$ - співвідношення показників ХСК/БСК 5 у водній витяжці волокнистої сировини: $1,42 \div 6,83$;

$\mathrm{X}_{3}$ - співвідношення показників БСК $/$ органічна частина у водній витяжці волокнистої сировини: $0,20 \div 0,84$

- група факторів, що характеризують параметри технологічного процесу:

$\mathrm{X}_{4}$ - температура зворотної води для розбавлення маси: $18 \div 90,{ }^{\circ} \mathrm{C}$;

$\mathrm{X}_{5}$ - ступінь млива маси: $25 \div 55,{ }^{0}$ ШР;

$\mathrm{X}_{6}$ - масова доля волокна: $0,25 \div 3,0, \%$;

група факторів, що характеризують стан зворотних вод:

$\mathrm{X}_{7}$ - масова концентрація розчинних органічних речовин у зворотній воді: $29 \div 1036$, мг/л;

$\mathrm{X}_{8}$ - співвідношення показників ХСК/БСК 5 у зворотній воді: $1,55 \div 4,83$.

\section{Перспективи подальших досліджень}

Наступним етапом проведення досліджень $є$ розробка максимально інформативної та шумостійкої матриці експериментальних досліджень та математичних моделей, які дають можливість використовувати їх для прогнозування стану технологічної системи.

\section{Список використаної літератури}

1. Плосконос В.Г. "Методологія дослідження динаміки функціонування складних систем виробництва паперу та картону» / Вісник НТУУ "КПІ" Хімічна інженерія, екологія та ресурсозбереження. Наук.зб. № 1(15), c.71-74. 
2. Плосконос В.Г. "Структурні аспекти взаємодії та математичні моделі елементів складних систем виробництва паперу та картону» / Вісник НТУУ "КПІ" Хімічна інженерія, екологія та ресурсозбереження. Наук.зб. № 2(16), с. 35-38.

Надійшла до редакції 27.04.2018 